\title{
Pentamidine, A New Diabetogenic Drug in Laboratory Rodents
}

\author{
P. Saï ${ }^{1}$, D. Boillot ${ }^{2}$, Ch. Boitard ${ }^{2}$, M. Debray-Sachs ${ }^{3}$, G. Reach ${ }^{2}$ and R. Assan ${ }^{2}$ \\ ${ }^{1}$ Veterinary School of Nantes, Nantes, ${ }^{2}$ Diabetes Department, Hôpital Bichat, Paris and ${ }^{3}$ Inserm U 25, Hôpital Necker, Paris, France
}

\begin{abstract}
Summary. The antiprotozoal drug, pentamidine, has been reported to induce hypoglycaemia associated with inappropriately high plasma insulin concentrations, followed by insulindependent diabetes mellitus. It has been suggested that this drug can be toxic to the islet B cell, inducing early cytolytic release of insulin leading to $B$ cell destruction. In order to test this hypothesis, mouse and rat islets were incubated with pentamidine at concentration range of $5 \times 10^{-11}$ to $5 \times 10^{-3} \mathrm{~mol} / 1$ and exposure times of 3-48 $\mathrm{h}$. The $\mathrm{B}$ cell responses to glucose + theophylline and to arginine were suppressed by pentamidine, while insulin release in non-stimulatory conditions was
\end{abstract}

increased. These effects were dose-dependent, time-dependent and irreversible. They were significant for $5 \times 10^{-7} \mathrm{~mol} / 1$ pentamidine, which is a concentration relevant to therapeutic uses. These effects developed more slowly than the toxic effects of streptozotocin and alloxan at the same molar concentration in vitro. ${ }^{51}$ Chromium release and Trypan blue exclusion tests support the hypothesis that pentamidine produces islet cell necrosis.

Key words: Pentamidine, diabetes mellitus, insulin secretion, $B$ cell, diabetogenic drugs.
The antiprotozoal drug, pentamidine, is an aromatic diamidine used for the chemotherapy of trypanosomiasis, leishmaniasis and Pneumocystis Carinii pneumonitis [1, 2]. Hypoglycaemic attacks have occurred in 91 cases [3-5]. Inappropriately high plasma insulin concentrations have been documented in some of these patients [3]. Diabetes mellitus has also been observed in 31 reported cases [6]. In eight of these subjects, diabetes developed after the occurrence of hypoglycaemia and was usually insulin-dependent. For these reasons we have suggested that pentamidine is toxic to B cells, inducing early cytolytic release of insulin, B cell destruction, insulinopenia and diabetes [3]. In order to check this hypothesis, mouse and rat islets were exposed to pentamidine in vitro, and basal and stimulated insulin release was measured.

\section{Material and Methods}

\section{Mouse and Rat Islet Preparations}

Adult DBA/2 mice and Wistar rats (CNRS, Orléans, France) fed ad libitum were used. Islets were prepared as described by Lacy and Kostianovsky [7], pancreatic tissue from five mice or one rat pancreas being treated with $15 \mathrm{mg}$ collagenase $(150 \mathrm{mU} / \mathrm{mg}$; Boehringer, Mannheim, FRG). After manual shaking, islets were picked up under a dissecting microscope (Nikon, SMZ 2, Tokyo, Japan) and transferred to Petri dishes set on ice. Islets were then either put on incubation plates or perifused directly.

\section{Incubation Experiments}

Five islets were suspended in each well of Falcon microtest plates (Becton-Dickinson, Rockville, Maryland, USA) in MEM Eagle medium (Flow Laboratories, Rockville, Maryland) supplemented with $10 \%$ fetal calf serum, glutamine $(2 \mathrm{mmol} / \mathrm{l})$, sodium pyruvate $(1 \mathrm{mmol} / \mathrm{l})$, non-essential amino-acids $(0.814 \mathrm{mg} / 1)$, streptomycin $(100 \mu \mathrm{g} / \mathrm{ml})$, penicillin $(100 \mathrm{mU} / \mathrm{l})$. This medium, containing glucose (5.5 mmol$/ 1)$, was equilibrated with $\mathrm{O}_{2}$ and $\mathrm{CO}_{2}(95 \%-5 \%)$ and the final $\mathrm{pH}$ was 7.4. The medium was called basal medium.

Pentamidine dimethane sulphonate (Specia, Paris, France) was dissolved in basal medium. Freshly isolated islets were incubated in basal medium ( 5 islets $/ 250 \mu \mathrm{l}$ ) for $24 \mathrm{~h}$ at $37^{\circ} \mathrm{C}$ with $\mathrm{O}_{2}$ and $\mathrm{CO}_{2}(95 \%$ and $5 \%$, in the presence of pentamidine $5 \times 10^{-11}$ to $5 \times 10^{-3} \mathrm{~mol} / 1$. Islets were also exposed to pentamidine $5 \times 10^{-3}$ and $5 \times 10^{-5} \mathrm{~mol} / \mathrm{l}$ for $3-48 \mathrm{~h}$.

At the end of the incubation period, islets were washed twice and then exposed to the basal or stimulatory media $(250 \mu \mathrm{l} /$ well $)$ for $30 \mathrm{~min}$. The standard stimulatory medium consisted of the basal medium, except for the addition of glucose $(16.5 \mathrm{mmol} / \mathrm{l})+$ theophylline $(5 \mathrm{mmol} / \mathrm{l})$. In other experiments, the basal medium was supplemented with arginine $(20 \mathrm{mmol} / 1)$. Similar experiments were performed with sodium methane sulphonate $\left(5 \times 10^{-5} \mathrm{~mol} / \mathrm{l}\right)$ in place of pentamidine dimethane sulphonate. To test the reversibility of pentamidine effects, islets were also exposed to pentamidine $5 \times 10^{-5} \mathrm{~mol} / 1$ for $24 \mathrm{~h}$, washed three times and re-incubated for $24 \mathrm{~h}$ in a pentamidinefree medium, before the stimulation described above. 


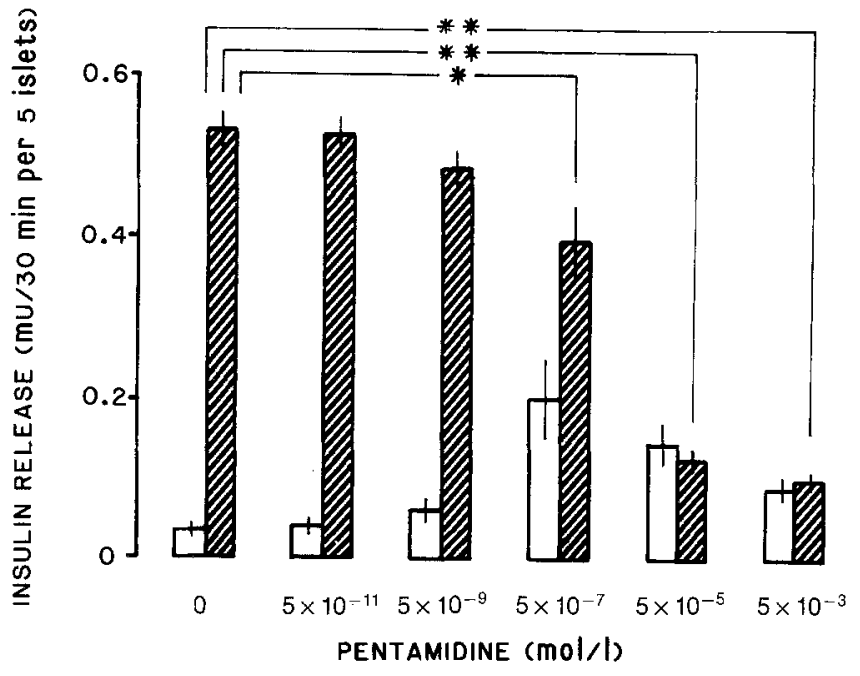

Fig. 1. Dose-dependency of pentamidine influence on B cells. Islets were incubated for $24 \mathrm{~h}$ in basal medium (glucose $5.5 \mathrm{mmol} / \mathrm{l}$ ) with various concentrations of pentamidine, then washed and exposed for $30 \mathrm{~min}$ to either a basal or a stimulatory medium (glucose, 16.5 $\mathrm{mmol} / 1+$ theophylline, $5 \mathrm{mmol} / \mathrm{l}) . \square=$ insulin basal release and $2=$ stimulated release. Results are presented as mean \pm SEM of five experiments. Asterisks at top of columns denote differences in stimulated IRI release between pentamidine-treated and control islets (**: $p<0.001 ; *: p<0.05$ )

\section{Direct Perifusion Experiments}

Freshly isolated islets were placed in a flow-through perifusion system $[8,9]$. Three perifusion media were prepared. The basal medium, derived from Krebs-Ringer physiological solution, contained the following components: $\mathrm{NaCl}(120 \mathrm{mmol} / 1), \mathrm{KCl}(4.7 \mathrm{mmol} / \mathrm{l}), \mathrm{MgSO}_{4}$ $(0.8 \mathrm{mmol} / \mathrm{l}), \mathrm{CaCl}_{2}(2.5 \mathrm{mmol} / 1), \mathrm{KH}_{2} \mathrm{PO}_{4}(1.2 \mathrm{mmol} / \mathrm{l}), \mathrm{NaHCO}_{3}$ $(25 \mathrm{mmol} / \mathrm{l})$, human serum albumin $(0.60 \%$; Centre National de Transfusion Sanguine, Paris, France), aprotinin $(2.000 \mu / \mathrm{ml}$; Choay, Paris, France), glucose $(5 \mathrm{mmol} / 1)$, sodium pyruvate, fumarate and glutamate $(5 \mathrm{mmol} / 1$ each; Sigma, St. Louis, Missouri, USA). The final $\mathrm{pH}$ was adjusted to 7.4 by adding 4-6 drops of normal sodium hydroxide. The stimulatory medium was essentially similar, except for glucose concentration which was $20 \mathrm{mmol} / \mathrm{l}$ and the addition of theophylline $(5 \mathrm{mmol} / \mathrm{l})$. The pentamidine-containing medium was similar to the basal medium, except for the addition of pentamidine $\left(10^{-4} \mathrm{~mol} / \mathrm{l}\right)$. Final $\mathrm{pH}$ was adjusted to 7.4 after complete dissolution of the drug. All three media were warmed to $37^{\circ} \mathrm{C}$ and gassed with a mixture of $\mathrm{O}_{2}+\mathrm{CO}_{2}(95 \%+5 \%)$ before and during perifusion experiments, the $\mathrm{pH}$ and temperature being repeatedly monitored. Chambers were perifused at a constant flow rate of $1 \mathrm{ml} / \mathrm{min}$. Experiments lasted for a maximum of $160 \mathrm{~min}$. Samples were collected at predetermined intervals of time, cooled on ice and frozen at $-20^{\circ} \mathrm{C}$ until assayed. Viability of islets was tested at the end of all experiments by the Trypan blue exclusion test.

\section{Incubation + Perifusion Experiments}

Freshly isolated islets were incubated for $18 \mathrm{~h}$ in supplemented MEM Eagle medium in the presence or in the absence of pentamidine $\left(10^{-4} \mathrm{~mol} / \mathrm{l}\right)$, then transferred to the perifusion chambers, perifused in basal medium for $40 \mathrm{~min}$ and stimulated by glucose $(20 \mathrm{mmol} /$ 1) + theophylline.

\section{Trypan Blue Exclusion Test}

Islets were exposed to a $0.5 \%$ Trypan blue isotonic solution for $1 \mathrm{~min}$, then examined under a dissecting microscope (Nikon SMZ2, Tokyo, Japan) under a white episcopic light, using $\times 40$ magnification.

\section{${ }^{51}$ Chromium Cytotoxicity Assay}

Dispersed islet cells were prepared as described previously (10) and their viability was tested by the Trypan blue exclusion test; only suspensions with at least $90 \%$ viable cells were retained. Cells were incubated at $37^{\circ} \mathrm{C}$ for $1-5 \mathrm{~h}$ with $80 \mathrm{mCi}$ of $\mathrm{Na}_{2}^{51} \mathrm{Cr} \mathrm{O}$ (CNTS, Paris, France), washed twice and then incubated for $24 \mathrm{~h}$ in the presence of pentamidine at a concentration range of $5.10^{-11}$ to $5.10^{-3} \mathrm{~mol} / 1$. The supernatants were counted in a gamma scintillation spectrometer (Packard, Chicago, Illinois). The ${ }^{51} \mathrm{Cr}$ release was compared with that of cells lysed with distilled water.

\section{Assessment of Hormone Damage}

During incubations, the insulin may have been partly damaged. This damage might have been reduced either by pentamidine, which is chemically close to the antiprotease molecule benzamidine [11], or augmented by the lysosomal enzymes of necrotic islet cells.

To assess the extent of insulin damage, ${ }^{125} \mathrm{I}$-insulin $(500 \mu \mathrm{Ci} / \mu \mathrm{g}-$ CNTS, Paris, France) was incubated with islets and pentamidine for 2 and $48 \mathrm{~h}$. Supernatants were then treated by dextran-coated charcoal [12]. It was assumed that the damaged hormone (i. e. free iodine and small peptides) corresponded to the fraction which was not retained by the dextran-coated charcoal.

\section{Determination and Expression of Results}

Insulin (IRI) was determined by radioimmunoassay [13] using charcoal for the separation of free and bound hormone, purified rat insulin as a standard and porcine ${ }^{125} \mathrm{I}$-insulin as a tracer. It was verified that pentamidine $\left(10^{-3} \mathrm{~mol} / \mathrm{l}\right)$ did not interfere with the assay. Results are expressed as mean \pm SEM. Statistical significance of differences was analysed by using the Student's t-test for non-paired values.

\section{Results}

\section{Influence of Pentamidine on the B Cell Responses to Stimuli}

Incubation Experiments: Dose-Dependency: As shown in Figure 1, mouse islets, incubated for $24 \mathrm{~h}$ in the basal control medium, responded to the stimulation by glucose $(20 \mathrm{mmol} / \mathrm{l})+$ theophylline $(5 \mathrm{mmol} / \mathrm{l})$ by a significant IRI release $(0.53 \pm 0.03$ versus $0.03 \pm 0.01 \mathrm{mU} /$ 30 min per five islets in basal medium, $n=6 ; p<0.001$ ). Pentamidine $\left(5 \times 10^{-9}\right.$ and $\left.5 \times 10^{-11} \mathrm{~mol} / \mathrm{l}\right)$ did not modify significantly this B cell response. But this response was significantly lower than control in islets treated by pentamidine $5 \times 10^{-7} \mathrm{~mol} / 1$. This response was abolished for concentrations of $5 \times 10^{-5}$ and $5 \times 10^{-3} \mathrm{~mol} / 1$.

Time-Dependency: this was analysed for pentamidine concentrations of $5 \times 10^{-5}$ and $5 \times 10^{-3} \mathrm{~mol} / 1$ (Fig. 2). While a significant $\mathrm{B}$ cell response to stimulus was observed in all control experiments (Fig. 2, upper panel), no response occurred in the case of islets exposed to pentamidine $5 \times 10^{-5} \mathrm{~mol} / 1$ and $5 \times 10^{-3} \mathrm{~mol} / 1$, from the shortest (i.e. $3 \mathrm{~h}$ ) to the longest $(48 \mathrm{~h})$ time of exposure (Fig. 2, central and lower panels). The B cell response from the pentamidine-treated islets was in all cases significantly lower than that from control islets in the same stimulatory medium. Thus suppression of IRI release was proportionate to the duration of exposure to the drug. 




Fig. 2. Time-dependency of the pentamidine influence on B cells. Islets were incubated for 3-48 $\mathrm{h}$ in basal medium (upper panel) or in basal medium containing pentamidine $\left(5 \times 10^{-5} \mathrm{~mol} / \mathrm{l}\right)$ (central panel) or $\left(5 \times 10^{-3} \mathrm{~mol} / 1\right)$ (lower panel). The islets were then washed and exposed to a basal or stimulatory medium as depicted in legend of Figure 1. Results are presented as in Figure 1. Experiments were performed in sextuplicate

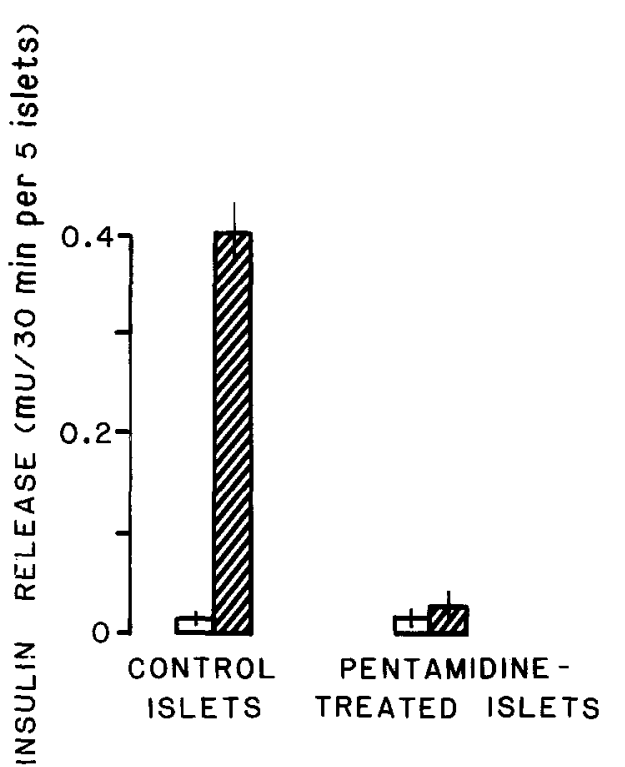

Fig. 3. Irreversibility of the pentamidine influence on B cells. Islets were incubated for $24 \mathrm{~h}$ in basal medium or in basal medium containing pentamidine $5 \times 10^{-5}$, then washed and incubated for a further $24 \mathrm{~h}$ in a pentamidine-free medium. They were then exposed for $30 \mathrm{~min}$ to either a basal or a stimulatory medium, as depicted in legend of Figure 1. Results are presented as in Figure 1. Experiments were performed in sextuplicate
When islets had been pre-incubated for $24 \mathrm{~h}$ with pentamidine $\left(5 \times 10^{-5} \mathrm{~mol} / \mathrm{l}\right)$, and then washed and allowed to stay for a further $24 \mathrm{~h}$ in a pentamidine-free medium, there was still no Bcell response to glucose + theophylline (Fig. 3).

When islets were treated with sodium methane sulphonate $\left(5 \times 10^{-5} \mathrm{~mol} / \mathrm{l}\right)$ for $24 \mathrm{~h}$ instead of pentamidine dimethane sulphonate, basal and stimulated IRI release was not different from control values: $0.03 \pm 0.01$ and $0.43 \pm 0.08 \mathrm{mU} / 30 \mathrm{~min}$ per five islets, respectively, versus $0.03 \pm 0.01$ and $0.43 \pm 0.10 \mathrm{mU} / 30 \mathrm{~min}$ per five islets respectively for the untreated control islets. When pentamidine-treated islets $\left(5 \times 10^{-3} \mathrm{~mol} / 1\right.$ for $\left.24 \mathrm{~h}\right)$ were stimulated by arginine ( $20 \mathrm{mmol}$ for $30 \mathrm{~min}$ ), no B cell response occurred: the basal value being $0.10 \pm$ $0.02 \mathrm{mU} / 30 \mathrm{~min}$ per five islets and the stimulated value $0.09 \pm 0.02 \mathrm{mU} / 30 \mathrm{~min}$ per five islets (versus $0.04 \pm 0 / 01$ and $0.15 \pm 0.05$ respectively in control experiments).

Incubation + perifusion: Islets were incubated for $18 \mathrm{~h}$ in supplemented MEM Eagle medium as described above in the presence or the absence of pentamidine $\left(10^{-4} \mathrm{~mol} / \mathrm{l}\right)$, then transferred to the perifusion system and stimulated by arginine $(20 \mathrm{mmol} / \mathrm{l})+$ theophylline $(5 \mathrm{mmol} / \mathrm{l})$. The B cell response in pentamidine-treated rat islets was dramatically lower than in control islets (Fig. 4, upper panel). In contrast, somatostatin release was similar to that in control islets (Fig. 4, lower panel). Similar results were obtained as regards the $\mathrm{B}$ cell response to glucose $(20 \mathrm{mmol} / \mathrm{l})+$ theophylline $(5 \mathrm{mmol} / \mathrm{l})$ from mouse or rat islets similarly treated by pentamidine then perifused in vitro (data not shown).

Direct perifusion experiments: Freshly isolated rat islets were perifused immediately, exposed to pentamidine $\left(10^{-4} \mathrm{~mol} / 1\right)$ for $40 \mathrm{~min}$, then stimulated by glucose $(20 \mathrm{mmol} / \mathrm{l})+$ theophylline $(5 \mathrm{mmol} / \mathrm{l})$. The mean IRI release following pentamidine exposure was $73 \pm 11$ versus $55 \pm 8 \mu \mathrm{U} / \mathrm{min}$ per 40 islets in control perifusions $(n=10 ; \mathrm{NS})$, but for the stimulatory period the mean increase in IRI secretion was lower in the pentamidinetreated islets than in the control islets $(0.04 \pm 0.01$ versus $0.08 \pm 0.01 \mathrm{mU} / \mathrm{min}$ per 40 islets; $p<0.05$ ). The switch from basal to pentamidine medium induced no massive IRI release during a 120 min observation period.

\section{Influence of Pentamidine on Non-stimulated IRI Release}

Incubation experiments: As already noted in Figures 1 and 2, pentamidine exerted complex influences on nonstimulated IRI release. In a dose-response study, pentamidine $\left(5 \times 10^{-9}\right.$ and $\left.5 \times 10^{-11} \mathrm{~mol} / \mathrm{l}\right)$ did not alter the basal IRI release in mouse islets at the end of the $24 \mathrm{~h}$ incubation period (Table 1). At concentrations of $5 \times 10^{-7}$ to $5 \times 10^{-3} \mathrm{~mol} / \mathrm{l}$, IRI release was dramatically increased. 
Table 1. Dose-response to pentamidine in basal medium (glucose $5.5 \mathrm{mmol} / \mathrm{l}$ )

\begin{tabular}{|c|c|c|c|c|c|c|}
\hline & $\begin{array}{l}\text { Control } \\
\text { islets }\end{array}$ & \multicolumn{5}{|c|}{ Pentamidine treated islets $(\mathrm{mol} / \mathrm{l})$} \\
\hline $\begin{array}{l}\text { Insulin release } \\
(\mathrm{mU} / 24 \text { h per } 5 \text { islets })\end{array}$ & $0.10 \pm 0.02$ & $0.10 \pm 0.01$ & $0.12 \pm 0.01$ & $1.35^{\mathrm{a}} \pm 0.09$ & $1.22^{\mathrm{a}} \pm 0.03$ & $0.45^{\mathrm{a}} \pm 0.03$ \\
\hline
\end{tabular}

Results expressed as mean \pm SEM of six experiments in each group.

Mouse-islets were incubated in basal medium for $24 \mathrm{~h}$ in the presence of pentamidine at various concentrations after which insulin was assayed in supernatant in absence of any further stimulation. ${ }^{a} p<0.001$ statistically significant difference from control islets

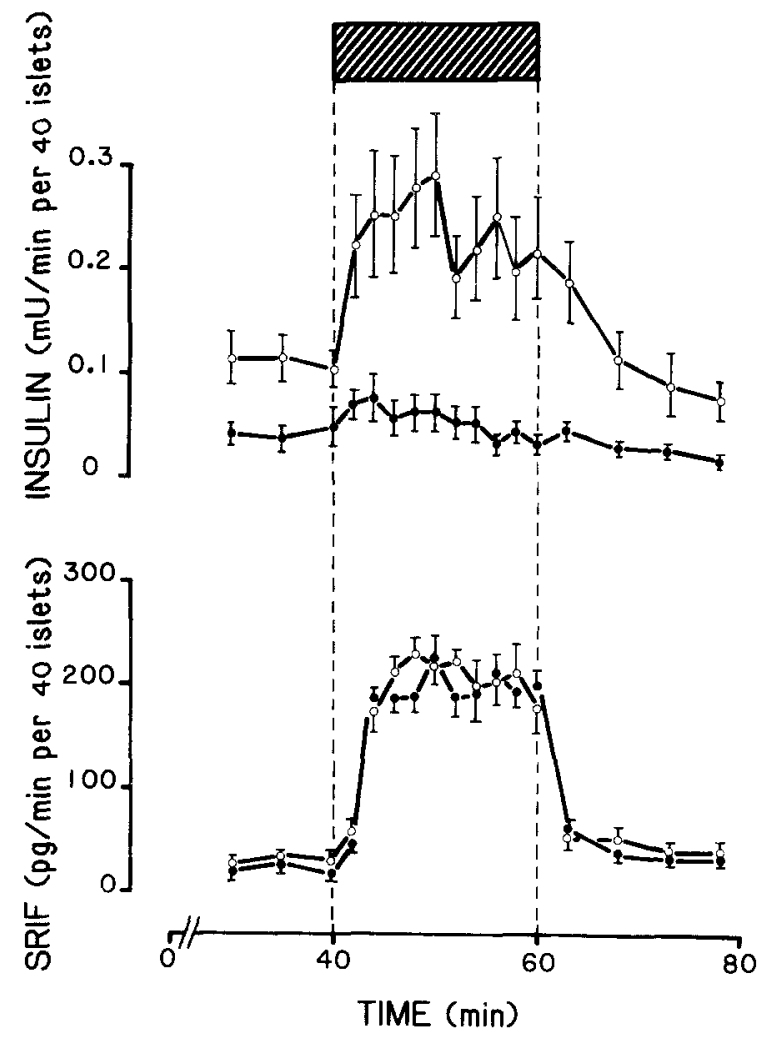

Fig. 4. Kinetics of the $\mathrm{B}$ and $\mathrm{D}$ cell responses to arginine + theophylline (incubation-perifusion experiments). Rat islets were pre-incubated with pentamidine $\left(10^{-4} \mathrm{~mol} / \mathrm{l}\right)$ for $18 \mathrm{~h}$, then placed in perifusion chambers and perifused with basal medium (glucose, $5 \mathrm{mmol} /$ 1) + theophylline $(5 \mathrm{mmol} / 1) . \mathrm{O}-\mathrm{O}=$ Control experiments (six experiments) and $-=$ pentamidine-experiments (six experiments). The hatched bar symbolizes the arginine + theophylline stimulation. Results are presented as mean \pm SEM

Islets were also serially incubated for $3-48 \mathrm{~h}$ to analyse the influence of the duration of the incubation period (Table 2). The IRI concentration in basal medium did not vary significantly. In the presence of the drug, the IRI level was markedly increased for the three shortest exposure times.

Modifications in hormone damage might have contributed to these complex effects of pentamidine.

${ }^{125}$ I-labelled insulin was incubated with basal medium plus islets in the absence and in the presence of pentamidine $\left(5 \times 10^{-3} \mathrm{~mol} / \mathrm{l}\right)$ and aprotinin $(20,000 \mathrm{U} /$ $\mathrm{ml})$. Incubations were conducted at $37^{\circ} \mathrm{C}$ for $2-48 \mathrm{~h}$. Aliquots of supernatants were then added to $500 \mu \mathrm{ldex}$ -
Table 2. Time dependency of insulin release after exposure to pentamidine $\left(10^{-3} \mathrm{~mol} / \mathrm{l}\right)$

\begin{tabular}{lllll}
\hline $\begin{array}{l}\text { Insulin release } \\
\text { (mU/5 islets } \\
\text { per time } \\
\text { of incubation) }\end{array}$ & \multicolumn{4}{l}{ Incubation time $(\mathrm{h})$} \\
\cline { 2 - 5 } & 3 & 18 & 24 & 48 \\
\hline $\begin{array}{l}\text { Control islets } \\
\begin{array}{l}\text { Pentamidine- } \\
\text { treated islet }\end{array}\end{array}$ & $0.09 \pm 0.01$ & $0.10 \pm 0.01$ & $0.09 \pm 0.01$ & $0.08 \pm 0.01$ \\
\hline
\end{tabular}

Results expressed as mean \pm SEM of six experiments in each group Islets were maintained in a non-stimulatory medium (glucose $5.5 \mathrm{mmol} / \mathrm{l}$ ) in the presence of pentamidine. Then insulin was assayed in supernatant in absence of any further stimulation. ${ }^{\mathrm{a}} p<0.001$ statistically significant difference between pentamidine-treated islets and the corresponding control group

tran-coated charcoal in the presence of $50 \mu$ normal sheep serum. The percentage radioactivity not retained by dextran-coated charcoal was increased in the supernatants after $48 \mathrm{~h}$ in the presence of pentamidine-treated islets: $57 \%$ versus $13 \%$ in case of control islets or tracer alone. This damage was slightly reduced $(52 \%$ instead of 57\%) by the addition of aprotinin. This suggests that the increase in basal IRI concentration observed after pentamidine exposure was not due to a reduction of hormone damage. On the contrary, the damage of tracer was increased, presumably due to cell necrosis and release of intracellular proteases. Similar results were obtained when ${ }^{125} \mathrm{I}$-glucagon was incubated with islets and pentamidine.

\section{Characterization of $B$ Cell Necrosis}

${ }^{51}$ Chromium release test: The chromium release from dispersed islet cells incubated for $24 \mathrm{~h}$ in basal medium with pentamidine $\left(5 \times 10^{-7}\right.$ to $\left.5 \times 10^{-3} \mathrm{~mol} / 1\right)$ was significantly higher than control values (Fig. 5). This increase was dose-dependent.

Trypan blue exclusion test: Dark blue islets were, in all instances, easily distinguishable from the bright white islets. The percentage of blue islets was $<1 \%$ in the case of control islets either freshly isolated or incubated for $18 \mathrm{~h}$ in MEM Eagle medium. It was also $<1 \%$ when islets were exposed to pentamidine $\left(10^{-4} \mathrm{~mol} / 1\right)$ for $120 \mathrm{~min}$ or less. This percentage increased progressively 


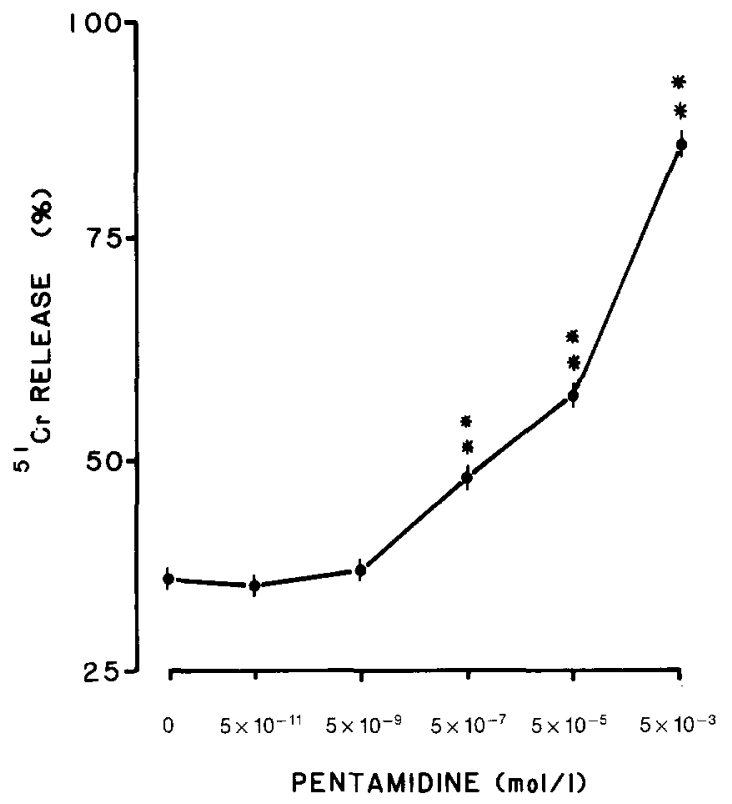

Fig.5. Chromium release from pentamidine-treated dispersed islet cells. Freshly prepared islet cells were treated with ${ }^{51} \mathrm{Chromium}$, then re-incubated for $24 \mathrm{~h}$ with pentamidine at various concentrations. The radioactivity in the supernatants was counted and compared with the ${ }^{51}$ Chromium release from control cells. These had been similarly prepared, incubated for $24 \mathrm{~h}$ in the absence of pentamidine, and then lysed by distilled water. Experiments were performed in triplicate. $* * p<0.001$

and reached $55 \%$ of islets after $5 \mathrm{~h}$. It was $95-100 \%$ after a 18 -h long exposure to the drug at a concentration of $10^{-4} \mathrm{~mol} / 1$. This time-course differed greatly from those obtained after exposure to streptozotocin or alloxan, the toxic effects of which were much faster than those of pentamidine at the same concentrations.

\section{Discussion}

Our data suggest that pentamidine exerts two distinct influences on the B cells: (1) an impairment of B cell response to glucose and arginine detectable as early as $1 \mathrm{~h}$ after exposure to the drug, and (2) a cytolytic process strongly suggested by ${ }^{51}$ Chromium release, the Trypan blue test and excessive release of insulin in non-stimulatory conditions. This leakage may be similar to that observed when alloxan and streptozotocin are used [14, 15], albeit less acute in the case of pentamidine than with alloxan [15]. Streptozotocin, added to dispersed islet cells incubated in vitro, induces a pattern very similar to that obtained with pentamidine, i. e. IRI release in non-stimulatory conditions and no response to glucose + theophylline (data not shown).

The clinical relevance of our experiments is substantiated by: (1) the time-course of published clinical events, where early hypoglycaemic attacks precede the onset of diabetes mellitus [3] and (2) the concentrations of pentamidine measured in plasma and tissues of treat- ed patients (i.e. $10^{-6} \mathrm{~mol} / \mathrm{l}$ ) which correspond to those toxic for islets in vitro $[16,18]$. Furthermore, in several patients with pentamidine-induced diabetes, renal insufficiency was present [3]. As pentamidine is partly excreted by the kidney, this condition may favour the accumulation of the drug in the tissues. In some cases, successive treatment courses have an additive effect on the impairment of glucose tolerance [3,20]. Although slight variations in glucose tolerance have been described in pentamidine-treated rabbits [21], no animal model of pentamidine-induced diabetes mellitus is currently available in vivo in laboratory rodents.

Two pentamidine salts are currently used in therapeutics: isethionate and mesylate (or dimethane sulphonate). The latter may be the more diabetogenic $[6,19$, 20]. Since isethionate can alter hormone release by itself [22], it is important to note that: (1) pentamidine dimethane sulphonate was used in the present study, and (2) sodium methane sulphonate had no effect. Further work is needed to clarify the mechanism of action of the drug on islet B cells at the molecular level. It has been shown in protozoa and bacteria that pentamidine interferes mainly with protein synthesis and ribosomal activities [23-26], with mitochondrial structure and oxidative metabolism [26-29]. It also impairs several enzymatic systems, including that of kallikrein [30], which may be involved in the insulin secretory process [31].

Islet $B$ cells were specifically affected by pentamidine in the concentration range studied here, while D cell function was not impaired. Further work, currently in progress, suggests that rat hepatocytes and some non-pancreatic cultured cell lines are less sensitive to the pentamidine toxicity than islet $\mathrm{B}$ cells. If confirmed, this would provide a new tool for the analysis of $B$ cell metabolism and further potential for the medical treatment of insulinomas.

Acknowledgements. We wish to express our gratitude to the following: Mrs. M. E. Royer and Mr. J. Mauduit (Spécia, France), Mrs. C. Maurel and H.Cohen for technical assistance, Mr. B. Treiber for editorial help. We also thank Professor E.Cerasi for helpful advice and discussions.

\section{References}

1. Rollo IM (1975) Pentamidine. In: Godman LS, Gilman A (eds) The pharmacological basis of therapeutics, 5th edn. MacMillan, New York, pp 1082-1083

2. Walzer PD, Perl DP, Krogstad DJ, Rawson PG, Schultz MG (1974) Pneumocystis carinii in the United States. Ann Int Med 80: 84-93

3. Bouchard Ph, Saï P, Reach G, Caubarrere I, Ganeval D, Assan R (1982) Diabetes mellitus following pentamidine-induced hypoglycemia in humans. Diabetes 31: 40-45

4. Grant AM, Sandler RM, Carell RW (1977) Hypoglycaemic effect of pentamidine detected by glucose screen. Lancet 2: 510-511

5. Barata L, Toth MV, Kosnai I, Szolnoki J (1974) Lebensbedrohliche Hypoglykämie unter Pentamidinbehandlung. Kinderärztl Prax 42: 131-134

6. Belehu A, Naafs B (1982) Diabetes mellitus associated with pentamidine mesylate. Lancet 1: 1463-1464 
7. Lacy PE, Kostianovsky M (1967) Method for the isolation of intact islets of Langerhans from the rat pancreas. Diabetes 16:35-39

8. Kikuchi M, Blackard WG, Renold AE (1974) Perifusion of pancreas fragments: a system for study of the dynamic aspects of insulin secretion. Diabetes 23: 550-559

9. Kervran A, Randon J, Girard JR (1979) Dynamics of glucose-induced plasma insulin increase in the rat fetus at different stages of gestation. Effects of maternal hypothermia and fetal decapitation. Biol Neonate 35: 242-248

10. Boitard C, Debray-Sachs M, Pouplard A, Assan R, Hamburger J (1981) Lymphocytes from diabetics suppress insulin release in vitro. Diabetologia 21: 41-46

11. Ensinck JW, Shepard C, Dudl RJ, Williams RH (1972) Use of benzamidine as a proteolytic inhibitor in the radio-immunoassay of glucagon in plasma. J Clin Endocrinol Metab 35: 463-467

12. Herbert V, Lau KS, Gottlieb CW, Bleicher S (1965) Coated charcoal immunoassay of insulin. J Clin Endorcrinol Metab 25: 1375-1380

13. Yalow RS, Berson SA (1960) Immunoassay of endogenous insulin in man. J Clin Invest 39:1157-1166

14. Goto Y, Berelowitz M, Frohman LA (1981) Acute effects of alloxan and streptozotocin-induced insulin deficiency on somatostatin and glucagon secretion by the perfused isolated rat pancreaticoduodenal preparation. Diabetologia 20: 66-71

15. Tomita T (1980) Effect of alloxan on insulin and glucagon secretion in perifused isolated islets. Diabetologia 19: 154-157

16. Launoy L, Gillo M, Jonchere H (1960) Etude du stockage et de l'élimination de la pentamidine chez la souris et le rat blanc. Ann Pharm Franc 18: 273-284 and 424-439

17. Waalkes TP, De Vita VT (1970) The determination of pentamidine (4,4-diamidinophenoxypentane) in plasma, urine and tissues. $\mathrm{J}$ Lab Clin Med 75: 871-878

18. Waalkes TP, Denham C, De Vita VT (1970) Pentamidine: clinical pharmacologic correlations in man and mice. Clin Pharmacol Ther 7: 505-512

19. Bryceson A (1968) Pentamidine-induced diabetes mellitus. East Afr Med J 45:110-117

20. Bryceson A, Woodstock L (1969) The cumulative effect of pentamidine dimethane sulphonate on the blood sugar. East Afr Med J 46: 170-173

21. Gasq M, Lapeyssonnie L (1949) Les diamidines aromatiques: inci- dents de traitement, action sur la glycémie. Med Trop (Mars) 9: 785-804

22. Pollard HB, Pazoles CJ, Creutz CE, Zinder O (1981) The chromaffin granule and possible mechanisms of exocytosis. Intern Rev Cytol 48: 159-197

23. Bornstein RS, Yarbro JW (1970) An evaluation of the mechanism of action of pentamidine isethionate. J Surg Oncol 2: 392-398

24. Williamson J, Macadam RF (1976) Drug effects on the fine structure of trypanosoma rhodesiense. Trans R Soc Trop Med Hyg 70: $130-137$

25. Kaplan HG, Myers CE (1977) Complex inhibition of thymidylate synthetase by aromatic diamidines: evidence for both rapid, freely reversible and slowly progressive non-equilibrium inhibition. $\mathbf{J}$ Pharmac 201: $554-563$

26. Pesanti EL, Cox C (1981) Metabolic and synthetic activities of pneumocystis carinii in vitro. Infect Immun 34: 908-914

27. Hill GC, Hutner SH (1968) Effects of trypanocidal drugs on terminal respiration of crithidia fascicula. Exp Parasitol 22: 207-212

28. Makulu DR, Waalkes TP (1975) Interaction between aromatic diamidines and nucleic acids: possible implications for chemotherapy. J Natl Cancer Inst 54: 305-309

29. Hentzer G, Kobayasi T (1977) The ultrastructural changes of leishmania tropica after treatment with pentamidine. Annals of tropical medicine and parasitology 71: 157-166

30. Geratz JD, Webster WP (1971) Inhibition of the amidase and kininogenase activities of pancreatic kallikrein by aromatic diamidines and an evaluation of diamidines for their in vivo use. Arch Int Pharmacodyn Ther 194: 359-370

31. Ole-MoiYoi O, Pinkus GS, Spragg J, Austen KF (1979) Indentification of human glandular kallikrein in the beta cell of the pancreas. N Engl J Med 300: 1289-1294

Received: 10 December 1982

and in revised form: 20 June 1983

Dr. Roger Assan

Diabetes Department

Hôpital Bichat

46 Rue Henri Huchard

F-75018 Paris

France 